\section{anthropology} \& materialism

\section{Anthropology \& Materialism}

A Journal of Social Research

\section{$3 \mid 2016$}

\section{Utopia: The Elsewhere and The Otherwise}

\title{
Casting a Picture
}

Utopia, Heimat and the Materialist Concept of History

En forgeant une image. Utopie, Heimat et le concept matérialiste d'histoire

Forjando una imagen. Utopía, Heimat y el concepto materialista de historia

\section{Cat Moir}

\section{OpenEdition}

Journals

Electronic version

URL: http://journals.openedition.org/am/573

DOI: $10.4000 / a m .573$

ISSN: 2364-0480

Publisher:

CETCOPRA, CRASSH - Center for Research in the Arts Social Sciences and Humanities, Fakultät

Gestaltung - Universität der Künste Berlin

\section{Electronic reference}

Cat Moir, "Casting a Picture », Anthropology \& Materialism [Online], 3 | 2016, Online since 15 December 2016, connection on 01 May 2019. URL : http://journals.openedition.org/am/573 ; DOI : 10.4000/ am.573

This text was automatically generated on 1 May 2019.

Tous droits réservés 


\title{
Casting a Picture
}

\author{
Utopia, Heimat and the Materialist Concept of History \\ En forgeant une image. Utopie, Heimat et le concept matérialiste d'histoire \\ Forjando una imagen. Utopía, Heimat y el concepto materialista de historia
}

\section{Cat Moir}

\section{Introduction}

\begin{abstract}
'Man everywhere is still living in prehistory, and
all and everything stands before the creation of the world, as a right one. True genesis is not at the beginning, but at the end, and is starts to begin only when society and existence become radical, that is, grasp themselves by their roots. But the root of history is the working, creating human being who reshapes and overhauls the given facts.

Once he has grasped himself and what is his, without expropriation and alienation, in real democracy, there arises in the world something that shines into the childhood of all, and in which no one has yet been: Heimat' (Bloch, 1996:

1375-1376). ${ }^{1}$
\end{abstract}

1 In 1961, Ernst Bloch was visiting West Germany with his wife Karola, when he heard the news that a wall had been erected in Berlin. That the Blochs had been granted a visa by the East German government confirms the privileged position they still enjoyed, though who knew for how much longer. Bloch had emigrated to the GDR in 1949, taking up a Professorship in Philosophy at the University of Leipzig. Initially full of enthusiasm for the new socialist state, he soon ran into trouble. His heterodox views, which highlighted the glaring gap between the regime's utopian rhetoric and the reality of life under dictatorship, quickly made him many enemies. His students were threatened, his publications blocked, and eventually in 1956 he was forced into retirement. Now, faced 
with the prospect of German division, Ernst and Karola decided to remain in West Germany, and Bloch's decision to flee was seen on both sides of the Iron Curtain as an acceptance that the utopian socialist project had failed.

Three years later, Bloch took part in a radio interview with Theodor Adorno on the contradictions of utopian longing. The discussion ranged over philosophy, art, and religion, but politics hovered in the background. When moderator Horst Krüger finally asked Bloch directly whether the utopian element had 'entirely disappeared from the socialism that rules the eastern world today', Bloch affirmed it had, with the caveat that 'it has also disappeared in the West and that similar tendencies exist that reproduce the unity of the epoch despite such great contrasts' (Bloch, 1988: 13). Adorno agreed that west and east were united in the conviction that 'nothing utopian should be allowed to exist' (ibid.). The reason why is unsurprising: Adorno and Bloch both agreed that utopia's essential function is 'as a critique of what is present' (Bloch, 1988: 12). Bloch's utopianism had been perceived as a threat to the GDR regime, yet despite the relative freedoms of capitalist democracy, he argued that it too was unable to tolerate utopia, in which the 'transformation of the totality,' as Adorno put it, is at stake (Bloch, 1988: 3).

3 This seems truer than ever today in a context in which the future can only be thought as either catastrophe or continuation (and therefore also catastrophe). The question with which Bloch and Adorno were concerned is thus still fundamentally a contemporary one: what is the value of utopian thought and practice today? Can we really imagine a better world? Can and should such images be a compass for political action? Adorno argued that '[o]ne may not cast a picture of utopia in a positive manner': only negatively, by criticising the status quo, can an image of utopia be adumbrated (Bloch, 1988: 10). On the contrary, Bloch insisted on the need to 'cast a picture' of utopia, which he saw as partly coming into being through its portrayal. 'As instalment of having been achieved it is already included when I portray it in a book,' he said (Bloch, 1988: 11). Such an idea must have been heretical to Adorno, whose commitment to the ban on images of utopia [ Bilderverbot] was in part motivated by the desire to avoid precisely the kind of abstract violence so often committed in its pursuit. ${ }^{2}$

Yet, as I will argue in this paper, Bloch's concept of Heimat demonstrates that he was just as much an iconoclastic utopian as Adorno (cf. Jacoby, 2005: 32-36). Bloch's concept of Heimat far from simply casts a picture in order to 'avoid the antinomy of death,' as Adorno saw the problem with the utopian image (Bloch, 1988: 10). Rather, it has much more in common with Walter Benjamin's dialectical image, in which the present can be perceived as the moment in which the demands of dead generations might be answered. These demands crystallise in Bloch's Heimat figure around the onset of capitalist modernity, when the European consciousness of time and space was reconfigured in a new understanding of history. I argue that, from a materialist perspective, we are still contemporaries of that moment, and thus the value of Bloch's utopia for materialist politics today lies in its ability to make the present visible as the site of a perpetual call for radical historical transformation.

\section{Utopia}

Something strange happened to the concept of utopia in the second half of the eighteenth century, which Bloch described as the 'transformation of the topos from space into time' (Bloch, 1988: 3). The early utopias of More, Bacon, Campanella, Schnabel and others that 
appeared in Europe from the early sixteenth century onwards had been primarily spatial fantasies, traveller's tales of sea voyages to remote, exotic islands inhabited by ideal communities that typically eschewed wealth and lived in harmony with nature. Thomas More's inaugural text tells the story of Raphael Hythloday, who travels to an island Utopia, where although 'no one owns anything, everyone is rich. For what can be greater riches than to live joyfully?' (More, 2003: 103). Meanwhile, J.G. Schnabel's Insel Felsenburg (1731-1743) is a utopian twist on the Robinsonade where the deserted traveller struggles to survive amidst an inhospitable nature (cf. Schnabel, 2006). Schnabel's story turns the tables, with the bankrupt protagonist Eberhard Julius shipwrecked on an island where the natural environment provides for the material needs of all. The depiction of these spatially distant worlds threw a critical light on contemporary Europe: the idea that a perfect society might exist somewhere else compensated for the ills perceived at home.

6 Louis-Sebastian Mercier's L'An 2440, rêve s'il en fut jamais of 1770 represented a sea change in the utopian imagination (Mercier, 1999). For the first time, the shortcomings of the here and now found their fulfilment not in another space, but in another time. After engaging in a heated debate with a philosopher friend about the injustices of life in contemporary Paris, the anonymous protagonist of Mercier's novel falls asleep and wakes to find himself transported to a Paris of the future. In Mercier's future, Paris looks just the same as it did in his own present, with the same streets and landmarks, but the injustices Mercier perceived in his own time have been eradicated. The constitutional monarchy still rules, but the estates have been replaced by a meritocratic elite; the Bastille is destroyed, the monarch has left Versailles and lives as a mere mortal; the death penalty is barely ever required, and when it is, only by those who voluntarily accept it out of guilt; marriages must be based on love and not on dowries, which perpetuate unequal social stratification. Mercier's future thus appears as the rational projection of a series of transformations already germinating in the Paris of the late eighteenth century, so much so that his contemporary C.M. Wieland described the book as 'the Last Judgment of the present constitution of France' (cited in Koselleck, 2002: 92). When revolution did in fact come in 1789 , Mercier retrospectively declared himself its prophet.

7 The reasons for what conceptual historian Reinhart Koselleck (2002: 84) has called this 'temporalization of utopia' can be found in two developments associated with the emergence of capitalist modernity: colonialism and secularisation. If in the 1730s it was still possible for Schnabel to imagine an undiscovered island harbouring a perfect community in the southern oceans, by 1770 this prospect seemed much less realistic: the same year Mercier's futuristic utopia was published, Cook had just explored the east coast of Australia. The idea of a perfect community had nowhere to go but to migrate out of space and into time. Yet the utopian future Mercier imagines is not divine, eternal realm, but a historical future, which assumes a spatial continuity with his contemporary, earthly Paris. The imagination of a historical future that would qualitatively transcend the present only became possible, as Peter Osborne has argued elsewhere, 'once Christian eschatology had shed its constant expectation of the imminent arrival of doomsday, and the advance of the sciences and the growing consciousness of the "New World" and its peoples had opened up new horizons of expectation' (Osborne, 1995: 11).

8 A utopia of the future, which relies for its credibility on a connection to the empirically redeemable present, must be underpinned by a linear philosophy of history. It is perhaps no wonder, then, that the temporalization of utopia should take place in the same historical moment in which progressive philosophy of history emerged. Koselleck names 
this moment the Sattelzeit, a period from around 1750-1850, which saw a radical transformation in historical consciousness. During the Sattelzeit, Koselleck argues, time becomes 'no longer simply the medium in which all histories take place; it gains a historical quality. Consequently, history no longer occurs in, but through time. Time becomes a dynamic and historical force in its own right' (2004: 246). The Enlightenment and the French Revolution fundamentally unsettled the traditional idea that predictions for the future could be made from the past: the future appeared radically open and undetermined by anything other than human will.

The concepts of radical incompletion and human authorship of history were combined in Rousseau's theory of perfectibility, which heavily influenced Mercier. If Rousseau argued that perfectibility, as an 'almost unlimited faculty' of the human species, was the condition of possibility for historical progress, then it was not in an unalloyed spirit of historical optimism (Rousseau, 2003: 141). For Rousseau, perfectibility led human beings away from an idealized, pre-political state of nature in which this distinctly human faculty was latent but undeveloped. Insofar as Rousseau saw its development resulting from contact among individuals, he tied historical degeneration to the advance of society, and in particular technology. At the heart of Rousseau's philosophy of history was thus a dynamic tension between progress and decadence, driven by humanity's essential incompletion.

Rousseau's concept of perfectibility would later be interpreted in a spirit of optimistic hubris, however. In 1793-94, Condorcet wrote in this vein that 'no limit has been determined for the perfecting of human faculties, that man's perfectibility is truly infinite, that the progress of this perfectibility, freed henceforth from any power who would stop it, has no limit but the duration of the globe on which we have been cast by nature' (cited in Brewer, 2008: 50). This construal of Rousseau is already present in Mercier's utopia, which combines a linear doctrine of progress with a strong sense of historical authorship. The protagonist finds himself, he says, on the rung of a progressive ladder of time, which will bring Paris to still greater heights (Koselleck, 2002: 90). Meanwhile, unlike in the spatial utopias that had gone before, in which the narrator reported a state of affairs that already existed pre-given somewhere and which he had happened across, with Mercier the dreaming protagonist becomes the authentic producer of his own vision.

11 In the interview with Adorno, Bloch describes the significance of this shift in the following terms. In the spatial utopia, he argues,

the wishland was still ready, on a distant island, but I am not there. On the other hand, when it is transposed into the future, not only am I not there, but utopia itself is also not with itself. This island does not even exist. But it is not something like nonsense or absolute fancy; rather it is not yet in the sense of a possibility; that it could be there if only we could do something for it. Not only if we travel there, but in that we travel there the island utopia arises out of the sea of the possible' (1988: 3).

12 By claiming this temporal sense of utopia as valid, despite the historical disappointment hopes placed in it have repeatedly suffered, Bloch identifies his utopianism as a variety of historical materialism committed to revolutionary progress and a strong sense of human agency (cf. Bloch, 1998: 339-345).

The materialist conception of a history that can be read from the distance of time is a question of the fulfilment of a moral demand: as Marx wrote in the $18^{\text {th }}$ Brumaire of Louis 
Bonaparte, 'Men make their own history, but they do not make it as they please; they do not make it under self-selected circumstances, but under circumstances existing already, given and transmitted from the past' (2010c: 103). From a materialist perspective, the task of history is 'not a question of drawing a great mental dividing line between past and future, but of realizing the thoughts of the past' (Marx, 2010a: 145), in particular those demands for freedom, equality, solidarity, justice - even, as Adorno affirmed, something so seemingly banal in a consumerist context as happiness - that remain unfulfilled. Certainly, the possibility of such a practice depends on a philosophy of history in which the future is at least partially undetermined and human beings have a measure of freedom to transform their environment. However, since human beings and their history are part of a larger reality, the question of transformative action must also have an ontological component. Bloch's utopianism can be seen as an attempt to provide an ontological foundation for the historical exigencies of a Marxist materialism.

Bloch's ontology locates the possibility of utopia's realisation in the constitution of the material world itself. Just as Kant's critical turn was an attempt to discover the conditions of possibility of a thought capable of asserting the categorical imperative of practical morality, Bloch's speculative turn considers what would have to be the case for Marx's reformulation of the categorical imperative - not only to interpret, but to change the world - to be capable of being answered. Bloch's ontology begins from the idea of being as a 'Not,' an absence from which something emerges but which is nonetheless preserved in the fabric of being as an original absence. In The Principle of Hope, he speaks of this

'Not with which everything starts up and begins, around which every Something is still built. [...] The Not is lack of Something and also escape from this lack: thus it is a driving towards what is missing' (1996: 306).

Being for Bloch is thus itself utopian because it is literally 'not (yet) there' in a fundamental sense. Miguel Abensour (2008: 408) summarises Bloch's utopian materialism succinctly when he says that 'To the extent that Being is thought at once as process and as incompletion, utopia and its persistence are inscribed in the very economy of Being'.

What Wayne Hudson (1982: 19-20) has called Bloch's central operator - the category of the Not-Yet - describes the tendency of the original lack in the material process to push out of itself towards the unrealised goals latent within it. By positing a deep connection between the 'Not-Yet-Become' content of the material world and a 'Not-Yet-Conscious' in the human being, Bloch makes the human into the author of a utopian history inscribed into the fabric of reality itself. The 'Not-Yet-Conscious in man,' he writes, 'belongs completely to the Not-Yet-Become, Not-Yet-Brought-Out, Manifested in the world. The Not-Yet-Conscious interacts and reciprocates with Not-Yet-Become, more specifically with what is approaching in history and in the world' (1996: 13). According to Bloch, by examining the unfulfilled demands of the past, human beings can analyse what Marx called the 'mystical consciousness that is unintelligible to itself' (Marx, 2010a: 145); by activating those demands in the pursuit of a just and peaceful future, we can come to possess in reality a thing of which the world itself has long dreamed, to which Bloch gives the name Heimat.

Adorno described as the 'innermost antinomy' of Bloch's thought, which he believed could not be resolved, that it 'conceives the end of the world as its ground, that which moves what exists, which, as its telos, it already inhabits' (1991: 213). Admittedly, Bloch concedes that 'both: Nothing and All - are still in no way decided as utopian characters, as threatening or fulfilling result-definitions in the world' (1996: 12). Nevertheless, Adorno's 
criticism is pertinent: it highlights what is at stake in the politics of the form, namely questions of teleology and totalization, which have been the subject of vigorous debate in the aftermath of the Soviet project. Matthew Charles (2010: 38) has put the criticism pointedly by arguing, via an interpretation of 'anticipatory illumination' [Vorschein] as the central utopian figure in Bloch's work, that 'the true historical meaning and implication of Bloch's utopianism' is 'Soviet socialism itself'.

Yet if, as Adorno claimed, the meaning of Bloch's utopianism resides in the fact that it 'makes the last first,' then it is not Vorschein but, as The Principle of Hope's literal last word, Heimat, which ought to be the key figure here. If we understand Heimat as the critical image of Bloch's utopia, however, a very different picture of its 'true historical meaning and implication' emerges. In particular, Heimat significantly complicates the idea of Bloch's utopianism as a linear, purely future-oriented temporal scheme.

\section{Heimat}

Something strange happened to the meaning of Heimat in the second half of the eighteenth century. In the German-speaking lands, the word traditionally denoted a birthplace or place of residence, particularly where matters of patrilineal inheritance and the right to social welfare were concerned. Until well into the nineteenth century the word was still used as a legal concept to define a person's domicile under what was known as Heimatrecht. The 1852 Brockhaus dictionary explained under Heimat the different laws of domicile in the German states, Austria, England and France. In this early sense, then, Heimat defined concrete spatial and temporal conditions, as well as precise legal and social relations. ${ }^{3}$

Around the turn of the nineteenth century, however, the word's meaning began to change. As the traditional, agrarian society in the German territories gave way to industrial class relations, labour became more mobile, and the rights previously associated with a Heimat acquired by birth were now afforded automatically after two years of residence in a place. The sense of dislocation that these social transformations engendered is registered in the semantic shift that Heimat underwent. Increasingly, it denoted not a geographical space, but an imaginary one, located in a romanticised past of childlike innocence and lost unity with nature.

For Friedrich Hölderlin, ancient Greece became the historical Heimat to which the modern present must look for inspiration in its time of crisis. ${ }^{4}$ In his novel Hyperion, Hölderlin speaks of a 'spiritual unity' with nature in the classical world, which is 'lost for us.' 'We are fallen with nature,' he says, 'and what was once one, as we may believe, is now resisting' (Hölderlin, 1946-1977: 236). ${ }^{5}$ Meanwhile, medieval Catholic Europe was Novalis' model of a past Heimat. In his 1799 fragment 'Christianity or Europe,' Hardenberg evokes a lost past of peace and innocence, when Europe was a culturally and spiritually unified entity bound by 'childlike faith' (Novalis, 1999: 60).

Early romantic philosophy of history thus stood in stark contrast to that of the enlightenment, but not only in the sense that the past, not the future, was the site of its historical sublime. Against a view of history as a linear continuum of progress, the romantics saw it as a cyclical or epochal process. In 'Christianity or Europe', Novalis asks whether 'oscillation, an opposition of opposed tendencies' is not proper to a thinking of history, explicitly rejecting 'progressive, constantly expanding evolution' (1999: 64). 
Meanwhile, Hölderlin speaks of humanity's 'eccentric path,' without the prospect of resolution (1946-1977: 558). Elizabeth Millán (2007: 168) confirms that the romantic philosophy of history was part of a broader worldview in which reality was seen as 'essentially incomplete'. ${ }^{6}$ Since human language is part of this incomplete reality, however, it cannot profess to its complete articulation. Friedrich Schlegel argued in this spirit that, "[p]ure thinking and cognition [Erkennen] of the highest can never be represented [dargestellt] adequately - this is the principle of the relative unrepresentability [Undarstellbarkeit] of the highest' (cited in Millán, 2007: 168). However, for Schlegel, this difficulty of representing the highest or infinite is overcome when philosophy embraces the techniques of poetic language, in particular irony, which signals insight into the impossible necessity of the task of representation. Philosophy, Schlegel claimed, 'is the real homeland [Heimat] of irony, which one would like to define as logical beauty: for wherever philosophy appears in oral or written dialogues - and is not simply confined into rigid systems - there irony should be asked for and provided' (ibid.). In other words, only through a fusion of poetry and philosophy can we sketch the contours of the ultimate.

It is clear, as Ivan Boldyrev (2014: 35) has argued elsewhere, that Bloch's writing is motivated by Schlegel's 'philosophical esprit.' However, while Boldyrev describes Bloch's stance as hovering 'between denying the system altogether and realizing that the system is indispensable, between the necessity and the impossibility of the absolute utterance' ( ibid.), I propose a rather less ambivalent reading. Bloch's literary style in no sense denies the need for systematic thought; rather, it acknowledges that the questions it addresses imply a totalizing perspective of which conventional philosophical language is incapable. Such a perspective can only be approximated by composing multiple fragments in a language that speaks not only to the mind, but also to the body. In Spirit of Utopia (2000: 193), Bloch writes of the ambivalence of a philosophical language that will do justice to speculative questions that ' $[\mathrm{t}]$ he simplest word is already much too much for it, the most sublime word much too little again.' As such, Bloch's language can be seen to embody Heimat in the Schlegelian sense that its literary form implies insight into the speculative nature of its pronouncements.

The final passage of Bloch's Principle of Hope, in particular, is saturated with romantic irony. The crucial sentence, on which everything hangs, stands out because it is italicised. If there were any doubt that the meaning of Bloch's utopianism resides in its last word, the text itself confirms it: 'True genesis is not at the beginning, but at the end.' And at the end we find the concept whose genesis is achieved, in Hegelian fashion, only through the process it embodies: Heimat. Yet the tension between the content of the assertion here and the form it takes performs a contradiction between the temporal coordinates of beginning and ending. The sentence literally 'makes the last first' by emphasising the end as the site of genesis; yet the imperfect figura etymologica in which cognate words signifying beginning - 'genesis,' 'beginning,' 'starts', but also the metaphor of rootedness - are successively repeated, over-determines Heimat as a search for origins.

Bloch understood such origins to be pure illusion just as well as the romantics did. As in Hölderlin's poem Homecoming (Hölderlin, 1998: 160), where 'Everything seems familiar; / Even people passing by greet each other as if they were / Friends, and every face appears like kin' the first thing that one notices about Bloch's Heimat is that it scheint. In other words, it offers the appearance of innocence and joy rather than providing them in reality. It is this symbolic sense of appearance as misleading ('all that glitters is not gold') that we 
find in Bloch's own vision of Heimat, which 'shines into the childhood of all'. Here, the double meaning of the word scheinen reiterates Bloch's insight into the nostalgic vision of the past as a false vision. Against Adorno's claim that Bloch's utopian traces are merely 'survivals of the ineffable experience of childhood which once upon a time communicated everything,' (Adorno, 1980: 49), Bloch explicitly acknowledges that 'no one has yet been' in such a childhood (1996: 1376).

Just as in Home (1998: 55), Hölderlin speaks to 'Kind river-banks that tended and brought me up,' and 'forests of my childhood,' Bloch's metaphor of roots at first appears to connect Heimat with the idea of a lost natural unity. Insofar as the romantic image of Heimat is 'always pastoral, in that its ideal resides in a state of nature', the figure of Rousseau once again haunts this picture (de Man, 2012: 110). Contra Marx, for whom Rousseau was the author of a survivalist Robinsonade (Marx, 2010d: 17), Bloch claims that '[e]ven wilderness, the apparently most extreme anti-pole to the world of men and plants,' was incorporated into Rousseau's image of nature as 'an Arcadia that had become sentimental' (Bloch, 1996: 389). Meanwhile, for Hölderlin (in whose mythic pantheon Rousseau's is the only historical name), Rousseau is neither the optimistic herald of linear progress evinced by Mercier, nor Bloch's nostalgic naturalist. '[S]eparation, pantheism and a temporal structure that moves from a remembered past to an ideal future' (de Man, 2012: 110) are the hallmarks of Hölderlin's Rousseau, whose concept of human perfectibility he interprets as an essentially endless process, the 'infinite approximation' [ unendliche Annäherung] of perfection (Hölderlin, 1946-1977: 558).

The relevance of Hölderlin's reading of Rousseau for Bloch's Heimat figure becomes clearer when we examine how the infinite approximation of perfection is expressed by Novalis. Heinrich von ofterdingen is a fragmentary novel telling of a medieval Minnesänger in search of a mystical union with divine nature. In the second part of Novalis' novel, the pilgrim meets a mysterious girl who responds to his questions with cryptic answers, and leads him away from his path. When he asks 'Where are we going?' she simply replies 'Always homeward [Immer nach Hause],' the word 'always' expressing the ultimate impossibility of reaching the intended destination (Novalis, 2008: 345). There is a clear parallel here with the structure of The Principle of Hope. The text opens with a series of questions: 'Who are we? Where do we come from? Where are we going? [Italics mine] What are we waiting for? What awaits us?' (Bloch, 1996: 3) and ends with the word 'Heimat' which - if read as a linear narrative - seems to stand as a definitive answer. However, given that the concept of Heimat is associated with the search for origins, our arrival at the end seems to return us to the same questions with which we began. The text can thus be seen simultaneously to perform linear and cyclical motions, oscillating between past and future in a way that calls attention to the present as a not-entirely-absent referent. For indeed, though Bloch refers to both past and future dimensions here, he invariably uses present-tense forms. Instead of being told that true genesis 'will come' at the beginning, we find that it 'comes'. Similarly, instead of saying that no one 'was' ever in a place like an imagined Heimat, Bloch opts for the present perfect 'has yet been.' Heimat 'will' not 'arise' in a world beyond expropriation and alienation: it 'arises."

Adorno (1992: 142) emphasizes a similar presencing technique in Hölderlin's poetry with reference to a particular line in Mnemosyne ('perhaps the most important text for deciphering Hölderlin philosophically'). It reads: 'But forward and backward we will / Not look,' and Adorno interprets this as expressing Hölderlin's observance of the Bilderverbot. He says: 
'Not forward: under the law of the present, which in Hölderlin is the law of poetry, with a taboo against abstract utopia, a taboo in which the theological ban on graven images, which Hölderlin shares with Hegel and Marx, lives on. Not backwards: because of the irretrievability of something once overthrown, the point at which poetry, history and ideal intersect' (ibid.).

Just as de Man argues that the romantic image of Heimat must remain 'always image,' because it can only conceive of that which 'is not in its present possession' (de Man, 2012: 110), so Adorno recognizes that Hölderlin's 'maxim of not looking backwards is directed against the chimera of origin' [Italics mine] (Adorno, 1992: 142). Bloch's philosophy of history shares with Hölderlin's an explicit orientation on Heimat as a human existence disalienated in every respect (cf. Mieth, 2007: 214). ${ }^{8}$ Yet in both cases, insofar as Heimat is about a search for origins, these must remain a goal, since what we seek in nostalgic visions of the past was never really there. ${ }^{9}$ According to Bloch, a nostalgic 'melancholy of fulfillment [...] accompanies anything invested with too much image' (Bloch, 1996: 234). Michael Löwy connects such naïve nostalgia with a 'reactionary romanticism', which he opposes with a 'revolutionary' variety such as we find in Benjamin and Bloch. Löwy argues that the aim of revolutionary romanticism is 'not a return to the past, but a detour through the past on the way to a utopian future' (Löwy, 2005: 5). Insight into the chimeric nature of the image thus calls attention to the insufficiency of a present that requires illusions about its own history. Yet for Bloch these illusions are not simply mythic: he rather interprets them as an index of the future as we might wish it to be. Since historical materialism is for Bloch the '[p]hilosophy...of the future' (1996: 9), it is therefore also that of the 'future in the past'.

\section{History}

Something strange happened to the concept of history in the second half of the eighteenth century. The German word for a narrative account of the past, Historie, was gradually swallowed up by the word for the events of the past, Geschichte (cf. Koselleck, 2004: 12). The one word now designated the past and the story we tell of it; reality and representation became inseparable. To understand why this happened, it is helpful to revisit Marx's understanding of the late eighteenth century as the moment when the industrial revolution produced the 'specifically capitalist mode of production' (cf. McNally, 1988: 14). The demands of mechanization and global distribution required homogeneity of time across large spatial distances. Jonathan Martineau stresses that the measure of clock-time is 'not a creation of [industrial] capitalism' per se, but spread throughout the transitional period of agrarian capitalism to form an increasingly standardized 'temporal infrastructure' (2015: 94). It was nevertheless capitalism, Martineau concedes, that would 'universalize this clock-time infrastructure and make it into the hegemonic form of time in capitalist societies' (2015: 95). In this context, the demands of capitalist time began to exert a homogenizing pressure on historical consciousness, and the distinction between narrative and chronological time was eroded.

Not incidentally, it was at just this moment that the academic discipline of history emerged in Germany, dominated by a historicist tradition whose aim was, in the words of its most famous representative Leopold von Ranke, to tell history 'as it actually was' [wie es eigentlich gewesen] (cf. von Ranke, 1885: VII). ${ }^{10}$ Of course, to tell history 'as it actually was' in fact meant to collapse the plurality of experience into a single, official 
representation. ${ }^{11}$ It is against precisely this historicist view that the materialist conception of history is articulated: not in the sense that materialist historiography is unconcerned with factual accuracy or methodological rigor (indeed, in this respect, as well as in its understanding of the radically historical character of human existence it shares much with other varieties of historicist thought that emerged in the same period). Rather, contrary to that form of historicism which, as Benjamin argues, 'musters a mass of data to fill...homogeneous, empty time', depoliticizing history by collapsing reality and representation, materialist historiography approaches its object as a 'revolutionary chance in the fight for the oppressed past' that escapes 'official' narratives (1968: 262-263).

Benjamin fleshes out this position in his XIV thesis on the philosophy of history, which proposes that 'History is the object of a construction whose place is formed not in homogenous and empty time, but in that which is fulfilled by the now [Jetztzeit]' (1968: 261). For Robespierre, Benjamin claims, referring obliquely to Marx's Eighteenth Brumaire (cf. Marx, 2010c: 104), 'Roman antiquity was a past charged with the now, which he exploded out of the continuum of history' (ibid.). This vision of history, in which the 'tradition of dead generations' becomes in the present the political demand for future redemption, is a historical materialism infused with the twin spirits of revolutionary romanticism and Jewish messianism. According to Löwy (2007: 7), messianism is for Benjamin 'at the heart of the Romantic conception of time and history'. Just as the romantics saw the past as a detour on the way to a utopian future, so too for Jewish messianism the "utopian content of the past becomes the material basis for a vision of the future' (Rabinbach, 1985: 84). Bloch cites in this context the 'myth of the Golden Age and its transposition into the future in the messianic consciousness of so many oppressed classes and peoples' as evidence that ' $[t]$ he good New is never that completely new' (Bloch, 1996: 60); the measure of historical novelty thus becomes the extent to which it answers the previously unfulfilled demands of the revolutionary tradition.

If in his 'Theological-Political Fragment', Benjamin declared that 'nothing that is historical can relate itself on its own account to anything messianic' (1968: 312), after 1924 he saw the dynamics of the sacred and profane orders as dialectically connected. In particular, the messianic present, as the moment of a demand for redemption, becomes Benjamin's key to interpreting the historical legacy of class struggle. It is on this basis that Benjamin develops the concept of the dialectical image as an instrument of a specifically materialist historiography. Benjamin provides his most complete articulation of the dialectical image in convolute $\mathrm{N}$ of the Arcades project, where he writes that

'It's not that what is past casts its light on what is present, or what is present its light on the past; rather, image is that wherein what has been comes together in a flash with the now to form a constellation. In other words, image is dialectics at a standstill. For while the relation of the present to the past is a purely temporal, continuous one, the relation of what-has-been to the now is dialectical: is not progression but image, suddenly emergent. - Only dialectical images are genuine images (that is, not archaic); and the place where one encounters them is language' (1999: 462).

The difficulties of interpretation of this passage are well known, and it is not possible here to do justice to the full scope of that debate..$^{12}$ However, I disagree with Susan BuckMorss, both in her assertion that Benjamin's concept is excessively opaque, and in her argument that it marks a sharp distinction between his thought and Bloch's (cf. BuckMorss, 1991, p. 67; p. 114). In an effort to decipher Benjamin's concept, we might recall 
here de Man's proposition that an image is only 'image' insofar as it depicts what is not in our present possession (2012: 112). In this spirit, Benjamin insists on a moment of dialectical synthesis in the image between 'what has been' - history as catastrophe, a Hegelian slaughter-bench at which the happiness of the great majority has been repeatedly sacrificed - and the 'now' as a demand for that continuum to be broken. It is in this sense, I argue, that Bloch's utopian Heimat must be recognized as a dialectical image after Benjamin.

Buck-Morss (1991: 114) argues that Benjamin, unlike Bloch, was 'reluctant to rest revolutionary hope directly on imagination's capacity to anticipate the not-yet existing'. Accordingly, Benjamin is said to have realised that even as wish image, 'utopian imagination needed to be interpreted through the material objects in which it found expression, for (as Bloch knew) it was upon the transforming mediation of matter that the hope of utopia ultimately depended: technology's capacity to create the not-yet known' (ibid.). Yet Bloch's and Benjamin's positions on these questions are a lot closer and a lot subtler than Buck-Morss allows. Bloch rested revolutionary hope simply on dreams no more than either he or Benjamin rested it simply on technology. In volume two of The Principle of Hope, Bloch explicitly examines various forms of technology as potential bearers of the desire for emancipatory transformation. Simultaneously, as we have seen, he invokes the concept of Heimat partly as a critique of technological 'progress'. Ultimately, though, for both Bloch and Benjamin, neither wishful images nor technology are sufficient without political action. Benjamin's concept of the dialectical image, and Bloch's articulation of it in the Heimat figure, make history as a call to action visible.

Here we find a stark contrast between Benjamin's and Bloch's fidelity to a certain conception of the image on the one hand, and Adorno's Bilderverbot on the other. Adorno's concept of the Bilderverbot arises from his continued commitment to that radical disconnection between the messianic and historical temporal orders, which Benjamin formerly espoused. For Adorno, the completely new represented by the messianic - the 'transformation of the totality', up to and including the transcendence of death - is so utterly unimaginable from the perspective of history that to make an image of it is not only strictly speaking impossible, but leads to the most aberrant politics. Adorno interprets Bloch's understanding of utopia as already partially achieved in the various images of it as indicative of a dangerous and complacent optimism in this regard: why act, if utopia is already achieved in images that guarantee the ultimate certainty of its advent?

But to read Bloch's concept of the utopian image as the mere projection of a goal immanently given as achieved is too simplistic: Bloch (1996: 47) readily admits that wishful images 'do nothing,' but rather insists that 'they depict and retain with particular fidelity what must be done'. Moreover, Adorno's stark opposition also results in ambiguity. Consider again his reading of the line from Hölderlin's Mnemosyne ('perhaps the most important text for deciphering Hölderlin philosophically'): 'But forward and back we will / Not look. Be rocked as / On swaying skiff of the sea.' Here Adorno claims the anacolutha in the second part of the verse reveals Hölderlin's 'intention to cast aside the synthesis of the image,' and 'trust to pure passivity in order to completely fulfill the present' (Adorno, 1992: 142). On the one hand, the charge of complacency is implicit in Adorno's critique of any fidelity to images of historical redemption. Yet Hölderlin's refusal to envision either the past or the future, which Adorno holds up as exemplary, can equally be seen to conjure the present as the site of a call, not for action, but for passive acceptance. 

makes clear, Bloch recognizes that the contents of the utopian Heimat image (harmony with nature, the 'real democracy' of Hölderlin's polis, and a society 'without expropriation and alienation') have never been achieved. ${ }^{14}$ Yet this is precisely the reason why images of utopia and of Heimat still have a historical purchase, above all as the products and inspiration of the historical agents of the required transformation. For Bloch, that agent is none other than 'the working, creating human being who reshapes and overhauls the given facts'. But what if history is, as Althusser (2001: 94) claimed, 'a process without a subject' capable of redeeming the political debts of the past? If all forms of Marxist humanism really are 'no more than ashes' (Althusser, 1969: 230), what hope is there 'to overthrow all relations in which man is a debased, enslaved, abandoned, despicable being'? (Marx, 2010b: 182).

42 An answer is perhaps to be found in Marx's Contribution to the Critique of Political Economy, written in 1859, after what Althusser considers his decisive anti-humanist turn. There, Marx claims that the 'bourgeois mode of production is the last antagonistic form of the social process of production' and that the 'prehistory of human society accordingly closes 
with this social formation' (Marx: 2010e: 263-4). However, the failure of the French Revolution to establish the freedom of the masses, not to mention the failure of successive attempts at proletarian revolution, mean that human beings everywhere 'still live in prehistory' according to Bloch: what Benjamin (1968: 263) calls the 'leap into the open sky of history' is yet to be achieved.

Bloch's emancipatory philosophy of history is thus not merely the Heimat of irony, cynically acknowledging itself as limited by its participation in the totalizing perspective it avows; it is also a variety of that materialist philosophy which, as Adorno (2004: 3) said of his own negative dialectics, 'lives on because the moment to realize it was missed'. Bloch's anticipatory response to Adorno was that the 'basic theme of philosophy which remains [...] is the still unbecome, still unachieved homeland [Heimat], as it develops outwards and upwards in the dialectical-materialistic struggle of the New with the old' (1996: 9). His dialectical image of Heimat asserts that a materialist interpretation of history will always be necessary, until the world is truly changed.

\section{Conclusion}

The eighteenth century was a moment in which, at the birth of modern capitalism, European conceptions of history (which, through the spread of capitalism itself, would exert themselves more or less forcefully around the world) were profoundly altered. The continued oppression, exploitation and alienation of human beings under capitalist conditions testify to the fact that we are still contemporaries of that historical moment. The ideology of progress, according to which what is currently the case is qualitatively superior to what has gone before simply by virtue of succeeding it chronologically, has failed. Meanwhile, contemporary consumerist nostalgia - the archaic vision of history so commonplace today, mistakes in its image of the past as a real historical sublime in which the deficiencies of the now never existed. Fred Jameson (2005: xi-xii) has argued that the 'relationship between utopia and the political, as well as questions about the practical-political value of utopian thinking and identification between socialism and utopia, very much continue to be unresolved topics today'. I hope this exegesis of Bloch's concept of a utopian Heimat has shown two things: first, that historical materialism needs images, albeit ones which it recognizes as not the thing itself. While Bloch and Benjamin understand this, Adorno equivocates. Second is that the value of Bloch's utopianism lies in its ability to highlight the historical debt the present owes to the catastrophic failures of past attempts at social liberation. Perhaps in this sense, utopia can recover its vitality as both a serious category of materialist historiography, and a 'politically energizing perspective' for the future (Jameson, 2005: xii).

\section{BIBLIOGRAPHY}

Abensour, Miguel, 'Persistent Utopia' in Constellations, Vol. 15, No. 3 (2008). 
Adorno, Theodor W., Minima Moralia: Reflexionen aus dem beschädigten Leben (Frankfurt am Main: Suhrkamp, 1969).

— 'Bloch's “Traces”: The Philosophy of Kitsch', trans. Rodney Livingstone, in New Left Review 121 (1980), pp. 49-62.

— Notes to Literature I, ed. Rolf Tiedemann, trans. Shierry Weber Nicholsen (New York: Columbia University Press, 1991).

— Notes to Literature II, ed. Rolf Tiedemann, trans. Shierry Weber Nicholsen (New York: Columbia University Press, 1992).

— Negative Dialectics (London: Routledge, 2004).

— Minima Moralia: Reflections from a Damaged Life (London: Verso, 2005).

Althusser, Louis, For Marx (London: The Penguin Press, 1969).

_ Lenin and Philosophy and other essays (New York: Monthly Review Press, 2001).

Bastian, Andrea, Der Heimatbegriff: Eine begriffsgeschichtliche Untersuchung in verschiedenen Funktionsbereichen der deutschen Sprache (New York: Walter de Gruyter, 1995).

Beiser, Frederick (ed.), The Early Political Writings of the German Romantics (Cambridge: Cambridge University Press, 1999).

Benjamin, Walter, Illuminations, ed. Harry Zohn (New York: Schocken Books, 1968).

— The Arcades Project (Cambridge, MA and London: Harvard University Press, 1999).

Bloch, Ernst, Das Prinzip Hoffnung (Frankfurt am Main: Suhrkamp, 1977).

- The Utopian Function of Art and Literature, ed. Jack Zipes (Cambridge, MA/London: MIT Press, 1988).

— The Principle of Hope (Chicago: MIT Press, 1996).

— Literary Essays (Stanford: Stanford University Press, 1998).

- Spirit of Utopia (Stanford University Press, 2000).

Boldyrev, Ivan, Ernst Bloch and his Contemporaries (London: Bloomsbury, 2014).

Brewer, David, The Enlightenment Past: Reconstructing Eighteenth-Century French Thought (Cambridge: Cambridge University Press, 2008).

Bronner, Stephen and Douglas Kellner, Passion and Rebellion: The Expressionist Heritage (South Hadley/Mass.: J.F. Bergin Publishers, 1983).

Charles, Matthew, 'Utopia and its Discontents: Dreams of Catastrophe and the End of the "End of History"' in Studies in Social and Political Thought, Vol. 18, (2010), pp. 29-40.

Düttmann, Alexander Garcia, "Dialectics and the Ban on Images" in The Memory of Thought: An Essay on Heidegger and Adorno (New York: London: Continuum Press, 2002), pp. 70-87.

Frank, Manfred, The Philosophical Foundations of Early German Romanticism (Albany: SUNY Press, 2012).

Friedlander, Eli, 'The Measure of the Contingent: Walter Benjamin's Dialectical Image,' in boundary 2, Vol. 35 (2008), pp. 1-25. 
Hamacher, Werner, "'NOW": Walter Benjamin and Historical Time' in Heridun Friese (ed.), The Moment: Time and Rupture in Modern Thought (Liverpool: Liverpool University Press, 2001), pp. 161-196.

Hölderlin, Friedrich, Sämtliche Werke. Große Stuttgarter Ausgabe (Stuttgart: Beck, 1946-1977).

- Selected Poems and Fragments, trans. Michael Hamburger, ed. Jeremy Adler (London: Penguin, 1998).

Holz, Hans Heinz, Logos Spermatikos: Ernst Blochs Philosophie der unfertigen Welt (Darmstadt/ Neuwied: Luchterhand, 1975).

Hudson, Wayne, The Marxist Philosophy of Ernst Bloch (London: Macmillan Press, 1982).

Jacoby, Russell, Picture Imperfect: Utopian Thought for an Anti-Utopian Age (New York: Columbia University Press, 2005).

Jameson, Fredric, Archaeologies of the Future: The Desire Called Utopia and Other Science Fictions (London: Verso, 2005).

Koselleck, Reinhart, The Practice of Conceptual History: Timing History, Spacing Concepts (Stanford, CA: Stanford University Press, 2002).

- Futures Past: On the Semantics of Historical Time (New York: Columbia University Press, 2004).

Löwy, Michael, Fire Alarm: Reading Walter Benjamin's 'On the Concept of History', trans. Chris Turner (London, New York: Verso, 2005).

Lukács, Georg, Goethe and his Age (New York: Grosset \& Dunlap, 1969).

de Man, Paul, 'Hölderlin and the Romantic Tradition,' in diacritics 40:1, 2012, pp. 100-129.

Martineau, Jonathan, Time, Capitalism and Alienation: A Socio-Historical Enquiry into the Making of Modern Time (Leiden, Boston: Brill, 2015).

Marx, Karl, Letter to Arnold Ruge, Kreuznach, September 1843, in Marx Engels Collected Works, Vol. 3 (London: Lawrence and Wishart, 2010a), pp. 141-145.

- 'Contribution to the Critique of Hegel's Philosophy of Law. Introduction', in Marx and Engels Collected Works, Vol. 3 (London: Lawrence and Wishart, 2010b), pp. 175-187.

- 'The Eighteenth Brumaire of Louis Bonaparte' in Marx Engels Collected Works, Vol. 11 (London: Lawrence and Wishart, 2010c), pp. 99-197.

- 'Economic Manuscripts of 1857-58' in Marx and Engels Collected Works, Vol. 28 (London: Lawrence and Wishart, 2010d).

- 'Contribution to the Critique of Political Economy' in Marx and Engels Collected Works, Vol. 29 (London: Lawrence and Wishart, 2010e), pp. 263-264.

Marx, Karl and Friedrich Engels, 'The Communist Manifesto', in Marx and Engels Collected Works, Vol. 6 (London: Lawrence and Wishart, 2010), pp. 477-519.

McNally, David, Political Economy and the Rise of Capitalism: A Reinterpretation (Berkeley, Los Angeles, London: University of California Press, 1988).

Mercier, Louis-Sébastien, L’An 2440, rêve s'il en fut jamais (Paris: Éditions La Découverte, 1999).

Mieth, Günther, Friedrich Hölderlin: Zeit und Schicksal. Vorträge 1962-2006 (Würzburg: Königshausen \& Neumann, 2007). 
Millán, Elizabeth, Friedrich Schlegel and the Emergence of Romantic Philosophy (Albany: SUNY University Press, 2007).

More, Thomas, Utopia, ed. George M. Logan and Robert M. Adams (Cambridge: Cambridge University Press, 2003).

Novalis, Heinrich von Ofterdingen in Gesammelte Werke (Frankfurt am Main: S. Fischer Verlag, 2008). Osborne, Peter, The Politics of Time: Modernity and Avant-Garde (London/New York: Verso, 1995).

Pensky, Max, 'Method and Time: Benjamin's dialectical images,' in David S. Ferris (ed.), The Cambridge Companion to Walter Benjamin (Cambridge: Cambridge University Press, 2004), pp. 177-198.

Rabinbach, Anson, 'Between Enlightenment and Apocalypse: Benjamin, Bloch and Modern German Jewish Messianism,' in New German Critique, 34 (1985), pp. 78-124.

von Ranke, Leopold, “Geschichten der romanischen und germanischen Völker von 1494 bis 1514. Zur Kritik neuerer Geschichtsschreiber” in Leopold von Ranke, Sämtliche Werke, Vol. 33/34 (Leipzig: Duncker \& Humblot, 1885).

Rousseau, Jean-Jacques, The Discourses and other early political writings, ed. Victor Gourevitch (Cambridge: Cambridge University Press, 2003).

Rühling, Christiane, Spekulation als Poesie: Ästhetische Reflexion und literarische Darstellung bei Schiller und Hölderlin (Berlin/Munich/Boston: Walter de Gruyter, 2015).

Schnabel, Johann Gottfried, Insel Felsenburg, ed. Volker Meid and Ingeborg Springer-Strand (Stuttgart: Reclam, 2006).

\section{NOTES}

1. I have slightly adapted the translation by Plaice, Plaice and Knight here.

2. For a detailed account of Adorno's concept of the Bilderverbot, see Alexander Garcia Düttmann, "Dialectics and the Ban on Images" in The Memory of Thought: An Essay on Heidegger and Adorno (New York: London: Continuum Press, 2002), pp. 70-87.

3. I am indebted to Andrea Bastian's (1995) conceptual history of Heimat here.

4. Admittedly Hölderlin's position in relation to romanticism is ambivalent. Paul de Man (2012: 119) sees Hölderlin as 'Standing at the beginning of the romantic tradition,' but he also 'points beyond it, away from it.' However, others clearly recognize Hölderlin's work as exemplary of early German romanticism: cf. Manfred Frank (2012).

5. The original sentence reads: 'Wir sind zerfallen mit der Natur, und was einst, als man glauben kann, Eins war, widerstreitet sich jetzt.'

6. Cf. also Christiane Rühling (2015: 2).

7. It is important to note that this is also the case in the original German, which also distinguishes between simple and compound (present) perfect and future tenses.

8. Original: 'Ihr geschichtsphilosophisches Denken und Sinnen ist auf in jedweder Hinsicht unentfremdetes menschliches Dasein gerichtet, auf "Heimat."

9. 'Origin is the goal,' first the motto of Austrian satirist Karl Kraus, is well known as the preface to Benjamin's XIV thesis on the philosophy of history, to which I turn in more detail below.

10. NB: the original essay was written in 1824.

11. For a detailed account of the political implications of the German historicist tradition ( Historismus), cf. George G. Iggers (1983), or more recently, Frederick Beiser (2011). 
12. Cf. in particular for useful discussions: Werner Hamacher (2001), Eli Friedlander (2008), and Max Pensky (2004).

13. Bloch's words in German - 'alles und jedes steht noch vor Erschaffung der Welt, als einer rechten' - clearly echo those in Adorno's text - 'Es gibt kein richtiges Leben im falschen.' Cf. Bloch (1977: 1628) and Adorno (1969: 26).

14. In his essay 'Hölderlin's Hyperion,' Georg Lukács claims that the poet 'remains faithful to the old revolutionary ideal of renovating polis democracy and is broken by a reality which had no place for his ideals, not even on the level of poetry and thought.' Cf. Lukács, (1969: 148).

\section{ABSTRACTS}

Drawing on Walter Benjamin's concept of the dialectical image, this paper reads Ernst Bloch's utopian Heimat figure as poetically staging the temporal dialectics of materialist history. Bloch combines romantic, messianic and materialist temporalities in a critique of the modern progress narrative, which inscribes historicity in the mere next-ness of each now. The continued oppression, exploitation and alienation of human beings under conditions of modern capitalism stands as testimony to the falseness of this assumption. Far from the simplistic teleology with which materialist theories of history in general, and Bloch's in particular, have so often been identified, utopia as Heimat sets up a complex spatiotemporal matrix which fixes the present as the locus of possibility of transformative action. Only by activating the unfulfilled claims of the past in the interest of a more just future can human beings occupy utopia: that is the meaning which I argue Bloch's Heimat image brings to bear on contemporary materialist thought and practice.

À partir du concept benjaminien d'image dialectique, cet article lit la figure utopique du Heimat, présente chez Ernst Bloch, comme une mise en scène poétique des temporalités dialectiques de l'histoire matérialiste. Bloch combine les temporalités romantique, messianique et matérialiste dans une critique du récit moderne du progrès, qui inscrit l'historicité dans la linéarité d'une simple succession temporelle. Le caractère durable de l'oppression, de l'exploitation et de l'aliénation des êtres humains au sein du capitalisme moderne témoigne de la fausseté de cette vision des choses. À distance de la téléologie simpliste à laquelle les théories matérialistes de l'histoire en général, et celle de Bloch en particulier, ont si souvent été identifiées, l'utopie comme Heimat développe une matrice spatio-temporelle complexe, au sein de laquelle le présent est le lieu où une action transformative est possible. C'est seulement en activant les revendications inaccomplies du passé dans l'intérêt d'un futur plus juste que les êtres humains peuvent occuper l'espace de l'utopie. Tel est, à mon sens, la signification que prend l'image blochienne du Heimat pour les réflexions et les pratiques matérialistes contemporaines.

En el marco del concepto de imagen dialéctica de Walter Benjamin, el presente artículo busca leer la figura utópica del Heimat en Ernst Bloch, como en emplazamiento poético de las dialécticas temporales de la historia materialista. Bloch combina la temporalidad romántica, la mesiánica y la materialista en una crítica al relato moderno del progreso, que inscribe la historicidad en la mera prolongación de cada presente. La continua opresión, explotación y alienación del ser humano bajo las condiciones del capitalismo moderno se exponen como testimonio de la falsedad de esta visión de cosas. Lejos de la teleología simplista con la cual las teorías materialistas de la 
historia han sido a menudo identificadas, tanto de modo general como también en Bloch, la utopía como Heimat plantea una matriz espacio-temporal compleja que fija el presente como un lugar donde una acción transformativa es posible. Sólo en la activación de las reivindicaciones incumplidas del pasado en miras a un futuro más justo, los seres humanos pueden ocupar la utopía: este es el significado que aporta, a mi parecer, la imagen del Heimat vista en Bloch, para las reflexiones y las prácticas materialistas contemporáneas.

INDEX

Mots-clés: Utopie, Heimat, matérialisme historique, image dialectique, Bloch

Palabras claves: Utopía, Heimat, materialismo histórico, imagen dialéctica, Bloch

Keywords: Utopia, Heimat, Historical Materialism, Dialectical Image, Bloch

\section{AUTHOR}

\section{CAT MOIR}

University of Sydney 